
\title{
Effect of Withholding Irrigation and Nitrogen Fertilization Level on Maize
Yield
}

\author{
E. E.A. El-Sobky and Nehal Z.A. El-Naggar \\ Agronomy Department, Faculty of Agriculture, Zagazig University, Zagazig, Egypt.
}

Received: $6 / 12 / 2016$

Accepted: 6/4/2017

\begin{abstract}
HIS INVESTIGATION was carried out in an demonstrated field at AlIbrahimia District, Sharkia Governorate, Egypt, during 2014 and 2015 seasons. The study aimed to find out the effect of withholding one irrigation at five stages as growth and three levels of $\mathrm{N}$ fertilization on maize (Zea mays $\mathrm{L}$.) yield and yield attributes. Withholding irrigation had significant effect on growth, yield and yield attributes of maize. Skipping the $3^{\text {rd }}, 5^{\text {th }}$ or $7^{\text {th }}$ irrigations reflected a significant decrease in both ear diameter and length, grain number per row, 100 -grain weight, grain weight per ear, maize yield per fad and harvest index. The increase of $\mathrm{N}$ level up to $120 \mathrm{~kg} \mathrm{~N} /$ fad gave significant increase in grain yield and almost all yield attributes and grain quality properties except harvest index which was decreased. The interaction between irrigation treatments and $\mathrm{N}$ levels affected grain yield per fad and some of its attributes where more $\mathrm{N}$ was needed for the maize stressed plants due to irrigation withholding. The grain yield response to $\mathrm{N}$ level was diminishing where $86.67 \mathrm{~kg} \mathrm{~N} /$ fad were needed to maximize the grain yield to $5.12 \mathrm{ton} /$ fad in normally irrigated plants.
\end{abstract}

Keywords Maize, Withholding Irrigation, Nitrogen, Grain Quality.

\section{INTRODUCTION}

In Egypt, the ever growing population dictates a continuous increase in the cultivated larea. This increase necessitates a progressive increase in irrigation water which already showed a great shortage. The 55.5 milliar $\mathrm{m}^{3}$ of water received through the river Nile do not satisfy the needs of the possible extension in the cultivated area. Therefore, efforts should always be paid to optimize the use of water in all activities and in particular in agriculture which receives the great part of available water resources. Therefore, the present study is one of the many attempts which must be devoted to optimize the use of irrigation water. This optimization is always made through keeping down the consumptive use through minimizing the amounts given per irrigation. Skipping one or more irrigation was always tried in order to optimize the use of irrigation water. Ibrahim \& Kandil (2007) reported that, the highest averages of plant height, ear characters (length, diameter and weight) as well as ears and grain yields of corn plants/fad were obtained under irrigation interval of 10 days followed by 14 and 18 days. Similarly, the highest values of grain chemical constituents of maize, i.e., total $\mathrm{P}$, total $\mathrm{N}$, carbohydrate and crude protein were obtained under the shortest irrigation interval. Also, Elzubeir \& Mohamed (2011) and Sokht-Abandani \& Ramezani (2012) reported that, water deficit irrigation in maize led to a significant decrease in numbers of row/ ear and number of grains/ row and ear. El-Shahed et al. (2013) revealed that, applying 6 irrigations gave the highest means of the different studied characters, i.e. growth and grain yield attributes followed by missing the $4^{\text {th }}$ and $6^{\text {th }}$ irrigations. On the other hand, SokhtAbandani \& Ramezani (2012) found that, ear diameter and length did not show a significant decrease due to prolonging the irrigation interval.

Mineral fertilization with nitrogen was also reported to increase growth and grain yield of maize. El-Murshedy (2002) and El-Sobky et al. (2014) reported that, the increase of $\mathrm{N}$ level up to 140 and $120 \mathrm{~kg} \mathrm{~N} /$ fad increased grain yield and its components, i.e. number of rows/ ear, number of grains/ row and ear, 100 kernels weight, grain weight and imaize grain yield. Also, Atia \& Mohamed (2006); Sokht-Abandani \& Ramezani (2012); Darwich (2013) and Hameedi et al. (2015) showed that, application of mineral $\mathrm{N}$ increased maize grain yield, biomass and its components of maize yield and its attributes. The

\#Corresponding author email: elsayedelsobky@yahoo.com

Tel. : +201289997689

DOI : $\quad 10.21608$ /agro.2017.453.1048

C2017 National Information and Documentaion Center (NIDOC) 
present study was devoted to find out the response of white maize yield to the effect of withholding one irrigation at five stages of maize growth compared with a control given seven irrigation at 12 days interval under three levels from $\mathrm{N}(40,80$ and $120 \mathrm{~kg} \mathrm{~N} / \mathrm{fad}$ ) and their interactions.

\section{MATERIALS AND METHODS}

The present study was conceded in an demonstrated field at Al-Ibrahimia District, Sharkia Governorate, Egypt, during 2014 and 2015 seasons. The study aimed to find out the effect of five irrigation withholding treatments and three levels of $\mathrm{N}$ fertilization on maize yield and yield attributes.

\section{Studied Factors}

Irrigation withholding treatments

Normal irrigation, receiving seven irrigations at 12 days interval.

Withholding the $3^{\text {rd }}$ irrigation at 46 days after planting (DAP)

Withholding the $4^{\text {th }}$ irrigation (58 DAP).

Withholding the $5^{\text {th }}$ irrigation (70 DAP).

Withholding the $6^{\text {th }}$ irrigation (82 DAP).

Withholding the $7^{\text {th }}$ irrigation (94 DAP).

Nitrogen fertilization levels

1. $40 \mathrm{kgN} / \mathrm{fad}$

2. $80 \mathrm{kgN} / \mathrm{fad}$

3. $120 \mathrm{~kg} \mathrm{~N} / \mathrm{fad}$

$\mathrm{N}$ levels were split and partly added before the first (22 DAP) and second (34 DAP) irrigations as ammonium nitrate $(33.5 \% \mathrm{~N})$.

\section{Experimental design}

A split plot design of four replications was used, where the irrigation withholding treatments were allocated in the main plots and $\mathrm{N}$ fertilization levels were allocated in sub plots $\left(17.5 \mathrm{~m}^{2}\right)$. Main plots were surrounded by wide borders $(2 \mathrm{~m})$ to avoid seepage of pwater among irrigated and un irrigated plots.

\section{Recorded dato}

\section{Maize yield and yield attributes}

At harvest, (120 days from planting), the following yield attributes were recorded on ten plants and ears: ear diameter $(\mathrm{cm})$, ear length (cm), rows number per ear, grains number per row, grains number per ear (calculated), 100grain weight $(\mathrm{g})$, shelling (\%) and grain weight per ear $(\mathrm{g})$. Also, the following final yield traits were recorded from the two central ridges: grain yield (ton/fad): at grain moisture content of 15.5 $\%$, ears yield, total yield, stover yield (ton/fad) and harvest index (\%) i.e., grain to total yield in percentage.

Grain samples at harvest were dried at $70^{\circ} \mathrm{C}$ up to constant weight where their contents from total $\mathrm{N}$ and total carbohydrates were determined, using the colorimeterical method according to Jackson (1967).

\section{General agronomic practices}

Single cross 10 maize cultivar (white) was planted on May $17^{\text {th }}$ in both seasons. Each sub plot $(3.5 \mathrm{~m} \times 5 \mathrm{~m})$ included 5 ridges $60 \mathrm{~cm}$ apart. Maize seeds were hand sown in hills $25 \mathrm{~cm}$ apart on one side of the ridge. Planting was made after Egyptian clover (Trifolium alexandrinum L.) as a preceding crop in both seasons using seeding rates of $10 \mathrm{~kg} /$ fad where plants were thinned to one plant per hill (28000 plant/ fad) before the first irrigation \(22 DAP) and flood irrigation was practiced every 12 days. Soil samples were collected from the experimental sites at the depth of $0-30 \mathrm{~cm}$ before planting to determine soil physical and chemical properties at the Central Laboratory of Faculty of Agriculture, Zagazig University, Zagazig, Egypt (Table 1).

\section{Statistical analysis}

Data were statistically analyzed according to Gomez \& Gomez (1984) by using MSTAT-C (1991) where statistical program Version 2.1 was used for analysis of variance (ANOVA). A combined analysis was undertaken for the data of the two seasons after testing the homogenity of the experimental errors. Treatment means were compared according to least significant differences (LSD) test. In the tables of the analysis of variance $*$,** indicate significant at 0.05 and 0.01 levels of probability, respectively as described by Sendecor \& Cochran (1982). In interaction Tables, capital and small letters were used to denote significant differences among rows and columns means, respectively. Interaction Tables are provided with response equations to compare the response of maize yield and its attributes to the increase of $\mathrm{N}$ level at the different irrigation treatments. The predicated maximum trait average (Ŷmax) which could have been obtained due to the addition of the predicted maximum $\mathrm{N}$ level (Xmax) are also included. The response equations were calculated according to Snedecor \& Cochran (1967) using the orthogonal polynomial Tables. The significancy of the linear and quadratic components of each of these equations was tested, then the response 
could be described as linear (first order) or quadratic (second order). The predicted maximum averages ( $\hat{\text { Ymax }}$ ) which could have been obtained due to the addition of the predicted maximum $\mathrm{N}$ level (Xmax) were calculated according to Neter et al. (1990) as explained by Abdul Galil et al. (2003) using the following equations:

$\hat{\mathrm{Y}}_{\max }=\hat{\mathrm{Y}}_{0}+\mathrm{b}^{2} / 4 \mathrm{c} \quad \mathrm{X}_{\text {max }}=\mathrm{X}_{0}+\mathrm{b} / 2 \mathrm{c}(\mathrm{u})^{p}$

where: $\hat{\mathrm{Y}}_{0}=$ Grain yield at the lowest $\mathrm{N}$ level, i.e. $40 \mathrm{~kg} \mathrm{~N} / \mathrm{fad}$ (ton/ fad). $\mathrm{b}=$ Measures the linear component of the response equation.

$\mathrm{c}=$ Measures the quadratic component of the response equation.

$\mathrm{u}=$ unit of $\mathrm{N}=40 \mathrm{~kg} \mathrm{~N} / \mathrm{fad}$.

Data in Table 2 show the monthly mean minimum and maximum air temperatures, relative humidity, wind speed and precipitation during the two maize growing seasons.

TABLE 1. Physical and chemical analyses of the experimental soil sites at $30 \mathrm{~cm}$ depth (average of two seasons).

\begin{tabular}{|c|c|c|c|c|c|}
\hline $\begin{array}{c}\text { Organic matter } \\
(\%)\end{array}$ & $\begin{array}{c}\text { Available } \mathbf{~} \\
\left(\mathbf{m g ~ k g} \mathbf{~ k g}^{-1}\right)\end{array}$ & $\begin{array}{c}\text { Available } \mathbf{P} \\
\left(\mathbf{m g ~ k g} \mathbf{~ k g}^{-1}\right)\end{array}$ & Available $\mathbf{~ ( \mathbf { m g ~ k g } ^ { - 1 } )}$ & $\mathbf{p H}^{\mathbf{a}}$ & Texture \\
\hline 2.10 & 45 & 8.0 & 140 & 7.90 & Clay \\
\hline
\end{tabular}

a: Soil suspension

TABLE 2. Monthly mean minimum and maximum air temperatures, relative humidity, wind speed and precipitation

at Al-Ibrahimia District during the two maize growing seasons *

\begin{tabular}{|c|c|c|c|c|c|c|}
\hline \multirow{2}{*}{ Month } & \multicolumn{3}{|c|}{ Temperature $\left({ }^{\circ} \mathrm{C}\right)$} & \multirow{2}{*}{$\begin{array}{l}\text { Relative humidity } \\
\text { (\%) }\end{array}$} & \multirow{2}{*}{$\begin{array}{l}\text { Wind } \\
(\mathrm{km} / \mathrm{h})\end{array}$} & \multirow{2}{*}{$\begin{array}{l}\text { Precipitation } \\
(\mathbf{m m})\end{array}$} \\
\hline & Max. & Min. & Mean & & & \\
\hline \multicolumn{7}{|c|}{2014 season } \\
\hline May & 42 & 25 & 33.5 & 71 & 13 & 0.00 \\
\hline June & 43 & 29 & 36 & 73 & 12 & 0.00 \\
\hline July & 39 & 31 & 35 & 82 & 10 & 0.00 \\
\hline August & 38 & 32 & 35 & 83 & 10 & 0.00 \\
\hline September & 39 & 28 & 33.5 & 74 & 9 & 0.00 \\
\hline \multicolumn{7}{|c|}{2015 season } \\
\hline May & 44 & 27 & 35.5 & 76.4 & 10 & 0.00 \\
\hline June & 40 & 28 & 34 & 77.4 & 10 & 0.00 \\
\hline July & 41 & 30 & 35.5 & 85.2 & 8 & 0.00 \\
\hline August & 42 & 33 & 37.5 & 80.9 & 10 & 0.00 \\
\hline September & 39 & 33 & 36 & 78.7 & 10 & 0.00 \\
\hline
\end{tabular}

\section{RESULTS AND DISCUSSION}

\section{Ear diameter and length}

Irrigation withholding treatments effect

The data presented in Table 3 revealed that, irrigation withholding was highly significant affecting both of ear diameter and length. The highest average of ear diameter was found under normal irrigation treatment and it was at par with withholding $4^{\text {th }}$ or $6^{\text {th }}$ irrigation treatments, according to the combined analysis. Missing the $3^{\text {rd }}$ and $7^{\text {th }}$ irrigation detected a significant decrease in both ear diameter and length. These results refer to a decrease in the current and stored photosynthates available for ear growth. Withholding the $3^{\text {rd }}$ irrigation coincided with early plant elongation whereas withholding the $7^{\text {th }}$ irrigation coincided with effective grain filling. These results are agreement with those reported by Hussein \& El-Melegy (2006) and Ibrahim \& Kandil (2007). However, Sokht-Abandani \& Ramezani (2012) found that ear diameter and length did not show significant differences as affected by irrigation intervals.

\section{Nitrogen level effect}

In both seasons and their combined, the increase of $\mathrm{N}$ level was followed by a significant 
TABLE 3. Ear diameter and length of maize as affected by irrigation withholding and nitrogen fertilization level and their interactions in the two seasons.

\begin{tabular}{|c|c|c|c|c|c|c|}
\hline \multirow[b]{2}{*}{ Main effects and interactions } & \multicolumn{3}{|c|}{ Ear diameter (cm) } & \multicolumn{3}{|c|}{ Ear length (cm) } \\
\hline & $\stackrel{N}{\mathscr{C}}$ & $\stackrel{N}{\ominus}$ & $\begin{array}{l}\varrho \\
\text { Ẽ } \\
\text { E. }\end{array}$ & $\stackrel{N}{\mathscr{E}}$ & $\stackrel{N}{\ominus}$ & $\begin{array}{l}\varrho \\
\stackrel{\varrho}{E} \\
\text { E. } \\
\text { ¿ }\end{array}$ \\
\hline Irrigation withholding(I): & & & & & & \\
\hline Control & $4.73 \mathrm{a}$ & $4.78 \mathrm{a}$ & $4.76 \mathrm{a}$ & $20.33 \mathrm{a}$ & $21.0 \mathrm{a}$ & $20.67 \mathrm{a}$ \\
\hline Withholding the $3^{\text {rd }}$ irrigation & $4.68 \mathrm{ab}$ & $4.65 \mathrm{ab}$ & $4.66 \mathrm{~b}$ & $19.58 \mathrm{~b}$ & $19.86 \mathrm{~b}$ & $19.72 b$ \\
\hline Withholding the $4^{\text {th }}$ irrigation & $4.75 \mathrm{a}$ & $4.73 \mathrm{a}$ & $4.74 \mathrm{a}$ & $20.94 \mathrm{a}$ & $20.61 \mathrm{a}$ & $20.78 \mathrm{a}$ \\
\hline Withholding the $5^{\text {th }}$ irrigation & $4.61 \mathrm{ab}$ & $4.63 \mathrm{~b}$ & $4.62 \mathrm{~b}$ & $20.58 \mathrm{a}$ & $20.64 \mathrm{a}$ & $20.61 \mathrm{a}$ \\
\hline Withholding the $6^{\text {th }}$ irrigation & $4.70 \mathrm{a}$ & $4.73 \mathrm{a}$ & $4.72 \mathrm{a}$ & $20.67 \mathrm{a}$ & $20.89 \mathrm{a}$ & $20.78 \mathrm{a}$ \\
\hline $\begin{array}{l}\text { Withholding the } 7^{\text {th }} \text { irrigation } \\
\text { Nitrogen level }(\mathbf{N}) \text { : }\end{array}$ & $4.59 \mathrm{~b}$ & $4.66 \mathrm{ab}$ & $4.63 \mathrm{~b}$ & $19.67 \mathrm{~b}$ & $19.67 \mathrm{~b}$ & $19.67 \mathrm{~b}$ \\
\hline $40 \mathrm{~kg} \mathrm{~N} / \mathrm{fad}$ & $4.71 \mathrm{a}$ & $4.65 \mathrm{~b}$ & $4.68 \mathrm{~b}$ & $19.49 \mathrm{~b}$ & $19.46 \mathrm{c}$ & $19.47 \mathrm{c}$ \\
\hline $80 \mathrm{~kg} \mathrm{~N} / \mathrm{fad}$ & $4.62 \mathrm{~b}$ & $4.68 \mathrm{~b}$ & $4.65 \mathrm{~b}$ & $20.54 \mathrm{a}$ & $20.51 \mathrm{~b}$ & $20.53 \mathrm{~b}$ \\
\hline $\begin{array}{l}120 \mathrm{~kg} \mathrm{~N} / \mathrm{fad} \\
\text { Interactions: }\end{array}$ & $4.71 \mathrm{a}$ & $4.75 \mathrm{a}$ & $4.73 \mathrm{a}$ & $20.86 \mathrm{a}$ & $21.36 \mathrm{a}$ & $21.11 \mathrm{a}$ \\
\hline $\mathrm{I} \times \mathrm{N}$ & N.S. & $*$ & N.S. & N.S. & $* *$ & $* *$ \\
\hline
\end{tabular}

*** and N.S. indicate significancy at 0.05 and 0.01 levels and insignificancy of differences, in respective order.

increase in both ear diameter and length. This response was in keeping up to the addition of 120 $\mathrm{kg} \mathrm{N} /$ fad (Table 3). Similar results were reported by Darwish (2003),Ash-Shormillesy (2005), Soliman \& Gharib (2011), Sokht-Abandani i\& Ramezani (2012) and El-Sobky et al. (2014).

\section{Interaction effect}

Results in Table 4 clearly indicate that maize plants were in need for more $\mathrm{N}$ up to $120 \mathrm{~kg} \mathrm{~N} /$ fad in order to compensate for the shortage of water caused by withholding the $3^{\text {rd }}$ irigation.
Normally irrigated plants or those missing the $5^{\text {th }}$ or the $6^{\text {th }}$ irrigation did not respond to the increase of $\mathrm{N}$ level indicating their normal performance regarding the growth of their ears.

Rows number per ear, grains number per row and ear

Irrigation withholding treatments effect

According to the combined analysis, withholding the $5^{\text {th }}$ irrigation, i.e. at 70 DAP, significantly decreased the number of grains per ear probably due to the decrease in the

TABLE 4. Ear length $(\mathrm{cm})$ of maize as affected by irrigation withholding and nitrogen fertilization level interaction (combined data).

\begin{tabular}{|c|c|c|c|}
\hline \multirow[b]{2}{*}{ Irrigation withholding } & \multicolumn{3}{|c|}{ N level } \\
\hline & $\begin{array}{c}40 \mathrm{~kg} \\
\mathrm{~N} / \mathrm{fad}\end{array}$ & $\begin{array}{l}80 \mathrm{~kg} \\
\mathrm{~N} / \mathrm{fad}\end{array}$ & $\begin{array}{l}120 \mathrm{~kg} \\
\mathrm{~N} / \mathrm{fad}\end{array}$ \\
\hline \multirow{2}{*}{ Normal irrigation } & $\mathrm{A}$ & $\mathrm{A}$ & $\mathrm{A}$ \\
\hline & $20.17 \mathrm{a}$ & $20.83 \mathrm{a}$ & $21.00 \mathrm{a}$ \\
\hline \multirow{2}{*}{ Withholding the $3^{\text {rd }}$ irrigation } & $\mathrm{B}$ & $\mathrm{B}$ & $\mathrm{A}$ \\
\hline & $18.50 \mathrm{~b}$ & $19.50 \mathrm{~b}$ & $21.17 \mathrm{a}$ \\
\hline \multirow{2}{*}{ Withholding the $4^{\text {th }}$ irrigation } & B & $\mathrm{AB}$ & $\mathrm{A}$ \\
\hline & $19.83 \mathrm{a}$ & $20.83 \mathrm{a}$ & $21.67 \mathrm{a}$ \\
\hline \multirow{2}{*}{ Withholding the $5^{\text {th }}$ irrigation } & $\mathrm{A}$ & $\mathrm{A}$ & $\mathrm{A}$ \\
\hline & $20.00 \mathrm{a}$ & $20.83 \mathrm{a}$ & $21.00 \mathrm{a}$ \\
\hline \multirow{2}{*}{ Withholding the $6^{\text {th }}$ irrigation } & $\mathrm{A}$ & $\mathrm{A}$ & $\mathrm{A}$ \\
\hline & $20.50 \mathrm{a}$ & $20.17 \mathrm{ab}$ & $21.67 \mathrm{a}$ \\
\hline \multirow{2}{*}{ Withholding the $7^{\text {th }}$ irrigation } & B & $\mathrm{A}$ & $\mathrm{A}$ \\
\hline & $17.83 \mathrm{~b}$ & $21.00 \mathrm{a}$ & $20.17 \mathrm{a}$ \\
\hline
\end{tabular}

Mean values in the same column for each trait followed by the same lower-case letter are not significantly different according to Duncan's multiple range test at $\mathrm{P} \leq 0.05$.

Egypt.J.Agron. Vol.39, No.1 (2017) 


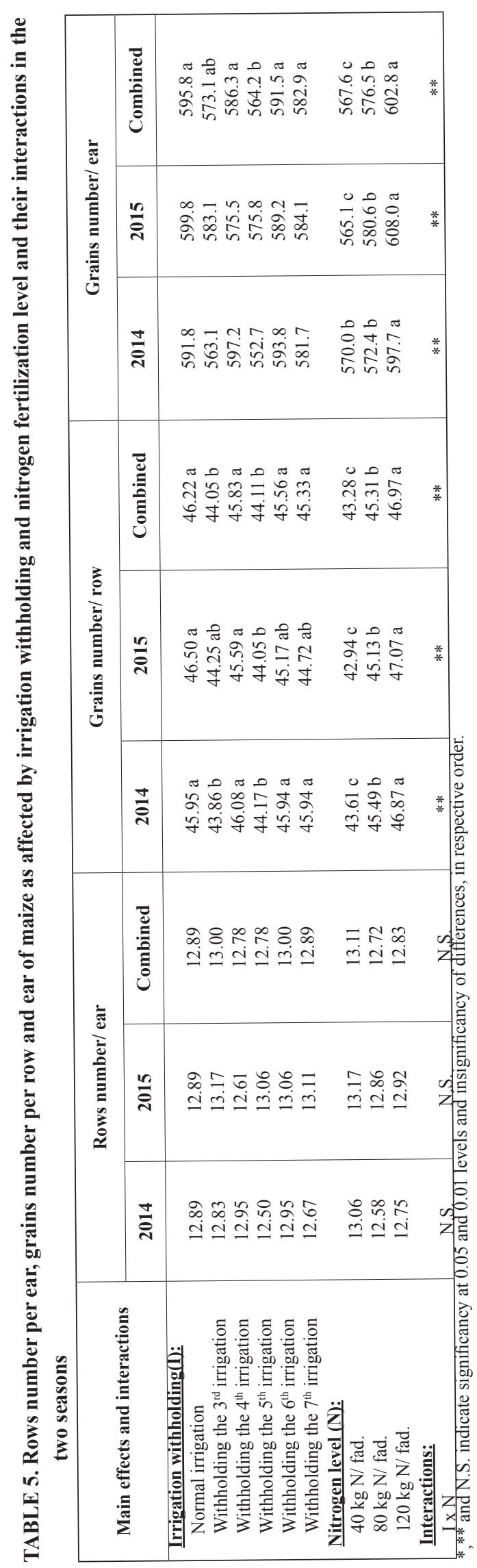

number of grains per row but not the number of rows per ear which did not vary significantly due to withholding any irrigation (Table 5). Similar results are reported by Elzubeir \& Mohamed (2011) and Sokht-Abandani \& Ramezani (2012).

\section{Nitrogen level effect}

In both seasons and their combined analysis, the number of rows per ear was not significantly increased due to the increase of $\mathrm{N}$ level (Table 5). However, number of grains per row and ear were increased significantly due to each $\mathrm{N}$ increase up to the addition of $120 \mathrm{~kg} \mathrm{~N} /$ fad. Moreover, these results refer to more photosynthesis which might had been available for grain set. Similar findings were reported by El-Metwally et al. (2001), Bader et al. (2003), Abd-Alla 『(2005), El-Azab (2012) and El-Sobky et al. (2014).

\section{Interaction effect}

The results in Tables 6 and 7 clearly indicate that withholding irrigation and in particular the $4^{\text {th }}$ or the $7^{\text {th }}$ irrigation might have had subjected maize plants to a decrease in $\mathrm{N}$ uptake which was compensated by more addition from $\mathrm{N}$ up to $120 \mathrm{~kg} \mathrm{~N} / \mathrm{fad}$. This response was not seen in the normally irrigated plants. Similar effects were observed in ear length (Table 4).

100-grain weight, grain weight per ear and grain yield

TABLE 6. Grains number per row of maize as affected by irrigation withholding and nitrogen fertilization level interaction (combined data).

\begin{tabular}{l|c|c|c}
\hline \multirow{2}{*}{$\begin{array}{l}\text { Irrigation } \\
\text { withholding }\end{array}$} & \multicolumn{3}{|c}{ N level } \\
\cline { 2 - 4 } & $\begin{array}{c}\mathbf{4 0} \mathbf{~ k g} \\
\text { N/ fad }\end{array}$ & $\begin{array}{c}\mathbf{8 0} \mathbf{~ k g} \\
\text { N/ fad }\end{array}$ & $\begin{array}{c}\mathbf{1 2 0} \mathbf{~ k g} \\
\text { N/ fad }\end{array}$ \\
\hline \multirow{2}{*}{\begin{tabular}{l} 
Normal irrigation \\
\cline { 2 - 4 }
\end{tabular}} & $\mathrm{A}$ & $\mathrm{A}$ & $\mathrm{A}$ \\
\hline $\begin{array}{l}\text { Withholding the } 3^{\text {rd }} \\
\text { irrigation }\end{array}$ & $\mathrm{B}$ & $\mathrm{B}$ & $\mathrm{A}$ \\
\cline { 2 - 4 } $\begin{array}{l}\text { Withholding the } 4^{\text {th }} \\
\text { irrigation }\end{array}$ & $\mathrm{B} .83 \mathrm{~b}$ & $42.50 \mathrm{~b}$ & $46.83 \mathrm{ab}$ \\
\cline { 2 - 4 } & $42.83 \mathrm{~b}$ & $46.67 \mathrm{a}$ & $48.00 \mathrm{a}$ \\
\hline $\begin{array}{l}\text { Withholding the } 5^{\text {th }} \\
\text { irrigation }\end{array}$ & $\mathrm{B}$ & $\mathrm{B}$ & $\mathrm{A}$ \\
\cline { 2 - 4 } $\begin{array}{l}\text { Withholding the } 6^{\text {th }} \\
\text { irrigation }\end{array}$ & $43.00 \mathrm{~b}$ & $43.50 \mathrm{~b}$ & $45.83 \mathrm{~b}$ \\
\hline $\begin{array}{l}\text { Withholding the } 7^{\text {th }} \\
\text { irrigation }\end{array}$ & $44.83 \mathrm{a}$ & $45.50 \mathrm{a}$ & $46.33 \mathrm{ab}$ \\
\cline { 2 - 4 } & $40.50 \mathrm{c}$ & $46.67 \mathrm{a}$ & $48.83 \mathrm{a}$ \\
\hline
\end{tabular}

Mean values in the same column for each trait followed by the same lower-case letter are not significantly different according to Duncan's multiple range test at $\mathrm{P}$ $\leq 0.05$. 
TABLE 7. Grains number per ear of maize as affected by irrigation withholding and nitrogen fertilization level interaction (combined data).

\begin{tabular}{|c|c|c|c|}
\hline \multirow{2}{*}{$\begin{array}{l}\text { Irrigation } \\
\text { withholding }\end{array}$} & \multicolumn{3}{|c|}{$\mathbf{N}$ level } \\
\hline & $\begin{array}{l}40 \mathrm{~kg} \\
\mathrm{~N} / \mathrm{fad}\end{array}$ & $\begin{array}{l}80 \mathrm{~kg} \\
\mathrm{~N} / \mathrm{fad}\end{array}$ & $\begin{array}{l}120 \mathrm{~kg} \\
\mathrm{~N} / \mathrm{fad}\end{array}$ \\
\hline \multirow{2}{*}{ Normal irrigation } & $\mathrm{A}$ & A & A \\
\hline & $594.7 \mathrm{a}$ & $610.3 \mathrm{a}$ & $582.3 \mathrm{ab}$ \\
\hline \multirow{2}{*}{$\begin{array}{l}\text { Withholding the } 3^{\text {rd }} \\
\text { irrigation }\end{array}$} & $\mathrm{B}$ & B & A \\
\hline & $554.7 \mathrm{ab}$ & $540.3 \mathrm{~b}$ & $624.3 \mathrm{a}$ \\
\hline \multirow{2}{*}{$\begin{array}{l}\text { Withholding the } 4^{\text {th }} \\
\text { irrigation }\end{array}$} & $\mathrm{C}$ & $\mathrm{B}$ & $\mathrm{A}$ \\
\hline & $544.0 \mathrm{~b}$ & $591.3 \mathrm{a}$ & $623.7 \mathrm{a}$ \\
\hline \multirow{2}{*}{$\begin{array}{l}\text { Withholding the } 5^{\text {th }} \\
\text { irrigation }\end{array}$} & $\mathrm{A}$ & $\mathrm{B}$ & $\mathrm{AB}$ \\
\hline & $575.0 \mathrm{a}$ & $551.7 \mathrm{ab}$ & $566.0 \mathrm{~b}$ \\
\hline \multirow{2}{*}{$\begin{array}{l}\text { Withholding the } 6^{\text {th }} \\
\text { irrigation }\end{array}$} & A & A & A \\
\hline & $584.7 \mathrm{a}$ & $589.0 \mathrm{a}$ & $600.7 \mathrm{a}$ \\
\hline \multirow{2}{*}{$\begin{array}{l}\text { Withholding the } 7^{\text {th }} \\
\text { irrigation }\end{array}$} & $\mathrm{C}$ & $\mathrm{B}$ & A \\
\hline & $552.3 \mathrm{ab}$ & $576.3 \mathrm{a}$ & $620.0 \mathrm{a}$ \\
\hline
\end{tabular}

Mean values in the same column for each trait followed by the same lower-case letter are not significantly different according to Duncan's multiple range test at $\mathrm{P} \leq 0.05$.

\section{Irrigation withholding treatments effect}

Irrigation withholding had significant effect on 100-grain weight, grain weight per earar and grain yield per fad (Table 8). Missing the $3^{\text {rd }}$ or the $7^{\text {th }}$ irrigation caused a significant decrease in both 100-grain weight and grain weight per ear maybe due to the coincidence of missing irrigations with restriction of grains number per row and grain filling, as was expected and repeatedly seen in all yield attributes. Grain yield per fad was significantly decreased by missing $3^{\text {rd }}$ or the $7^{\text {th }}$ irrigation by 10.35 and $16.20 \%$, respectively. This could be attributed to the decreased of grain yield per fad which was significantly decreased with missing the $3^{\text {rd }}$ and $7^{\text {th }}$ irrigation. These results are in close agreement with the results obtained by Ibrahim \& Kandil (2007), Elzubeir \& Mohamed (2011) and El-Shahed et al. (2013).

\section{Nitrogen level effect}

According to the combined analysis, each increase in $\mathrm{N}$ level was positively led to an increase in 100-grain weight and grain yield per fad (Table 8). The consistent increase of grain yield/ fad, with each increase in $\mathrm{N}$ level could be attributed to the increase of grain yield components (Tables 5 and 8). Similar findings were reported by Atia \& Mohamed (2006), Sokht-Abandani \& Ramezani (2012), Darwich (2013) and Hameedi et al. (2015).

Interaction effect

Results in Tables 9 show that grain weight/ ear

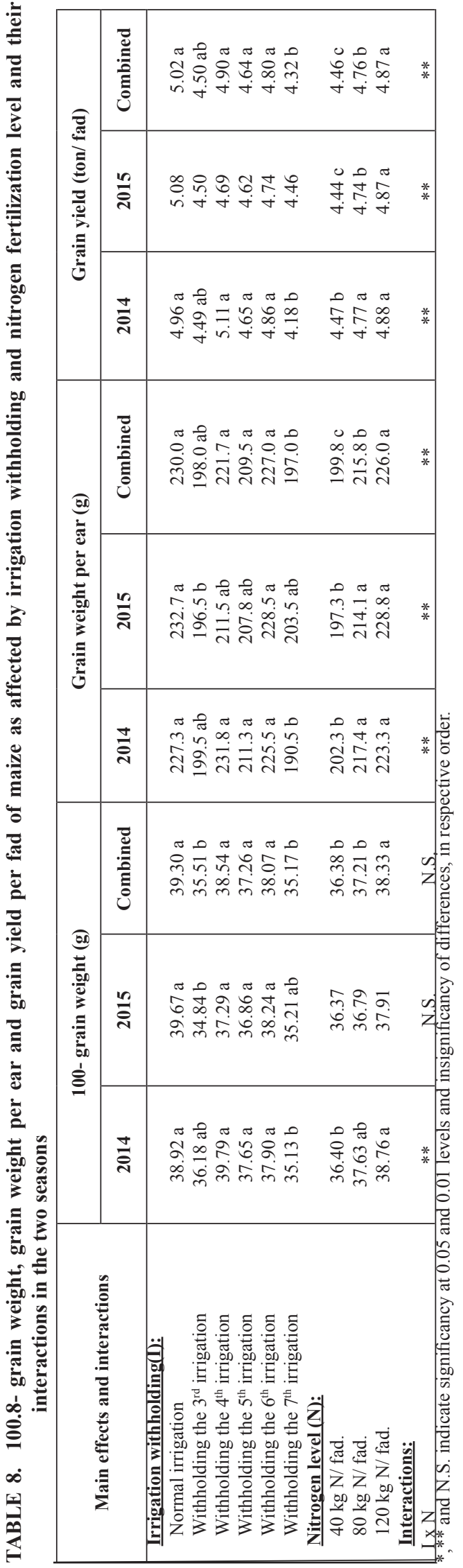


was significantly increased in only those plants which were subjected to shortage of water due to withholding any irrigation except the $5^{\text {th }}$ irrigation. This effect was also reflected in the response of grain yield per fad (Table 10) to the increase to $\mathrm{N}$ level. The response was quadratic in most cases where $86.67 \mathrm{~kg}$ $\mathrm{N} /$ fad were enough to maximize yield to $5.12 \mathrm{ton} /$ fad in normally irrigated plants whereas $100.4 \mathrm{~kg} \mathrm{~N} /$ fad were needed to maximize yield to $4.78 \mathrm{ton} / \mathrm{fad}$ when the $7^{\text {th }}$ irrigation was withhold.

\section{Ears, stover and total yields and harvest index}

Irrigation withholding treatments effect

The results summarized in Table 11 revealed that, according to combined analysis, irrigation withholding significantly affected ears, stover and total yields. Ears yield was decreased by $14.78 \%$ when missing the $7^{\text {th }}$ irrigation and both the stover and the total yields/fad were decreased by 22.66 , 19.51 and $17.73,17.27 \%$ when missing the $3^{\text {rd }}$ or the $7^{\text {th }}$ irrigation, respectively compared with normal irrigation treatment. Similar significant effects were observed in some yield attributes (Tables 3, 5 and 8). While, missing the $5^{\text {th }}$ irrigation led to a significant decrease in harvest index. These results are in accordance with those reported by Ibrahim \& Kandil (2007), Farre \& Faci (2009) and Iqbal et al. (2010).

\section{Nitrogen level effect}

Addition of $120 \mathrm{~kg} \mathrm{~N} /$ fad produced a significant increase in ear yield/ fad in the second season and the combined analysis. However, stover and total yields/ fad did not show significant difference between adding 80 or $120 \mathrm{~kg} \mathrm{~N} / \mathrm{fad}$. But, the combined
TABLE 9. Grain weight per ear (g) of maize as affected by irrigation withholding and nitrogen fertilization level interaction (combined data).

\begin{tabular}{|c|c|c|c|}
\hline \multirow{2}{*}{$\begin{array}{l}\text { Irrigation } \\
\text { withholding }\end{array}$} & \multicolumn{3}{|c|}{$\mathbf{N}$ level } \\
\hline & $\begin{array}{l}40 \mathrm{~kg} \\
\mathrm{~N} / \mathrm{fad}\end{array}$ & $\begin{array}{l}80 \mathrm{~kg} \\
\mathrm{~N} / \mathrm{fad}\end{array}$ & $\begin{array}{l}120 \mathrm{~kg} \\
\mathrm{~N} / \mathrm{fad}\end{array}$ \\
\hline \multirow{2}{*}{ Normal irrigation } & A & A & A \\
\hline & $227.0 \mathrm{a}$ & $230.0 \mathrm{a}$ & $233.0 \mathrm{ab}$ \\
\hline \multirow{2}{*}{$\begin{array}{l}\text { Withholding the } 3^{\text {rd }} \\
\text { irrigation }\end{array}$} & $\mathrm{B}$ & $\mathrm{B}$ & A \\
\hline & $191.0 \mathrm{a}$ & $189.0 \mathrm{~b}$ & $214.0 \mathrm{~b}$ \\
\hline \multirow{2}{*}{$\begin{array}{l}\text { Withholding the } 4^{\text {th }} \\
\text { irrigation }\end{array}$} & $\mathrm{B}$ & $\mathrm{A}$ & A \\
\hline & $201.5 \mathrm{a}$ & $235.5 \mathrm{a}$ & $228.0 \mathrm{ab}$ \\
\hline \multirow{2}{*}{$\begin{array}{l}\text { Withholding the } 5^{\text {th }} \\
\text { irrigation }\end{array}$} & A & $\mathrm{A}$ & $\mathrm{A}$ \\
\hline & $200.5 \mathrm{a}$ & $209.0 \mathrm{ab}$ & $219.0 \mathrm{ab}$ \\
\hline \multirow{2}{*}{$\begin{array}{l}\text { Withholding the } 6^{\text {th }} \\
\text { irrigation }\end{array}$} & $\mathrm{B}$ & $\mathrm{B}$ & $\mathrm{A}$ \\
\hline & $218.0 \mathrm{a}$ & $220.5 \mathrm{a}$ & $242.5 \mathrm{a}$ \\
\hline \multirow{2}{*}{$\begin{array}{l}\text { Withholding the } 7^{\text {th }} \\
\text { irrigation }\end{array}$} & $\mathrm{B}$ & A & $\mathrm{A}$ \\
\hline & $161.0 \mathrm{~b}$ & $210.5 \mathrm{ab}$ & $219.5 \mathrm{ab}$ \\
\hline
\end{tabular}

Mean values in the same column for each trait followed by the same lower-case letter are not significantly different according to Duncan's multiple range test at $\mathrm{P} \leq 0.05$.

analysis detected significant decrease in harvest index due to the increase of $\mathrm{N}$ level to 80 or $120 \mathrm{~kg}$ $\mathrm{N} /$ fad which produced at par significant decrease in harvest index (Table 11). Similar results were obtained by Mohamed (2006), Achieng et al. (2010), El-Azab (2012) and Sokht-Abandani \& Ramezani (2012), Abd El-Rheem et al. (2015) and Mahama et al. (2016).

TABLE 10. Grain yield (ton/ fad) of maize as affected by irrigation withholding and nitrogen fertilization level interaction (combined data).

\begin{tabular}{|c|c|c|c|c|c|c|}
\hline \multirow[b]{2}{*}{ Irrigation withholding } & \multicolumn{3}{|c|}{ N level } & \multirow[b]{2}{*}{$\hat{\mathbf{Y}}=\mathbf{a}+\mathbf{b x}-\mathbf{c} \mathbf{x}^{2}$} & \multirow[b]{2}{*}{$\underline{\hat{\mathbf{Y}}}_{\underline{\underline{\max }}}^{\underline{\text { (ton/fad) }}}$} & \multirow[b]{2}{*}{$\underset{\substack{\underline{X}_{\max } \\
\underline{(\mathrm{kg} \mathrm{N} / \mathrm{fad})}}}{ }$} \\
\hline & $\begin{array}{l}40 \mathrm{~kg} \\
\mathrm{~N} / \mathrm{fad}\end{array}$ & $\begin{array}{c}80 \mathrm{~kg} \\
\text { N/ fad }\end{array}$ & $\begin{array}{l}120 \mathrm{~kg} \\
\mathrm{~N} / \mathrm{fad}\end{array}$ & & & \\
\hline \multirow{2}{*}{ Normal irrigation } & A & A & A & \multirow{2}{*}{$4.92+0.35 x-0.15 x^{2}$} & \multirow{2}{*}{5.12} & \multirow{2}{*}{86.67} \\
\hline & $4.92 \mathrm{a}$ & $5.12 \mathrm{a}$ & $5.02 \mathrm{a}$ & & & \\
\hline \multirow{2}{*}{ Withholding the $3^{\text {rd }}$ irrigation } & $\mathrm{B}$ & $\mathrm{B}$ & A & \multirow{2}{*}{$4.43+0.65 x$} & \multirow{2}{*}{ Linear } & \multirow{2}{*}{ Linear } \\
\hline & $4.43 \mathrm{a}$ & $4.21 \mathrm{~b}$ & $4.85 \mathrm{a}$ & & & \\
\hline \multirow{2}{*}{ Withholding the $4^{\text {th }}$ irrigation } & $\mathrm{B}$ & $\mathrm{A}$ & $\mathrm{A}$ & \multirow{2}{*}{$4.46+1.39 x-0.57 x^{2}$} & \multirow{2}{*}{5.31} & \multirow{2}{*}{88.77} \\
\hline & $4.46 \mathrm{a}$ & $5.28 \mathrm{a}$ & $4.96 \mathrm{a}$ & & & \\
\hline \multirow{2}{*}{ Withholding the $5^{\text {th }}$ irrigation } & $\mathrm{B}$ & $\mathrm{AB}$ & A & \multirow{2}{*}{$4.41+0.09 x$} & \multirow{2}{*}{ Linear } & \multirow{2}{*}{ Linear } \\
\hline & $4.41 \mathrm{a}$ & $4.58 \mathrm{ab}$ & $4.92 \mathrm{a}$ & & & \\
\hline \multirow{2}{*}{ Withholding the $6^{\text {th }}$ irrigation } & A & A & A & \multirow{2}{*}{$4.86-0.33 x+0.16 x^{2}$} & \multirow{2}{*}{4.69} & \multirow{2}{*}{81.25} \\
\hline & $4.86 \mathrm{a}$ & $4.69 \mathrm{a}$ & $4.84 \mathrm{a}$ & & & \\
\hline \multirow[b]{2}{*}{ Withholding the $7^{\text {th }}$ irrigation } & $\mathrm{B}$ & A & A & \multirow[b]{2}{*}{$3.65+1.50 x-0.5 x^{2}$} & \multirow[b]{2}{*}{4.78} & \multirow[b]{2}{*}{100.4} \\
\hline & $3.65 \mathrm{~b}$ & $4.65 \mathrm{ab}$ & $4.66 \mathrm{a}$ & & & \\
\hline
\end{tabular}

Mean values in the same column for each trait followed by the same lower-case letter are not significantly different according to Duncan's multiple range test at $\mathrm{P} \leq 0.05$. 


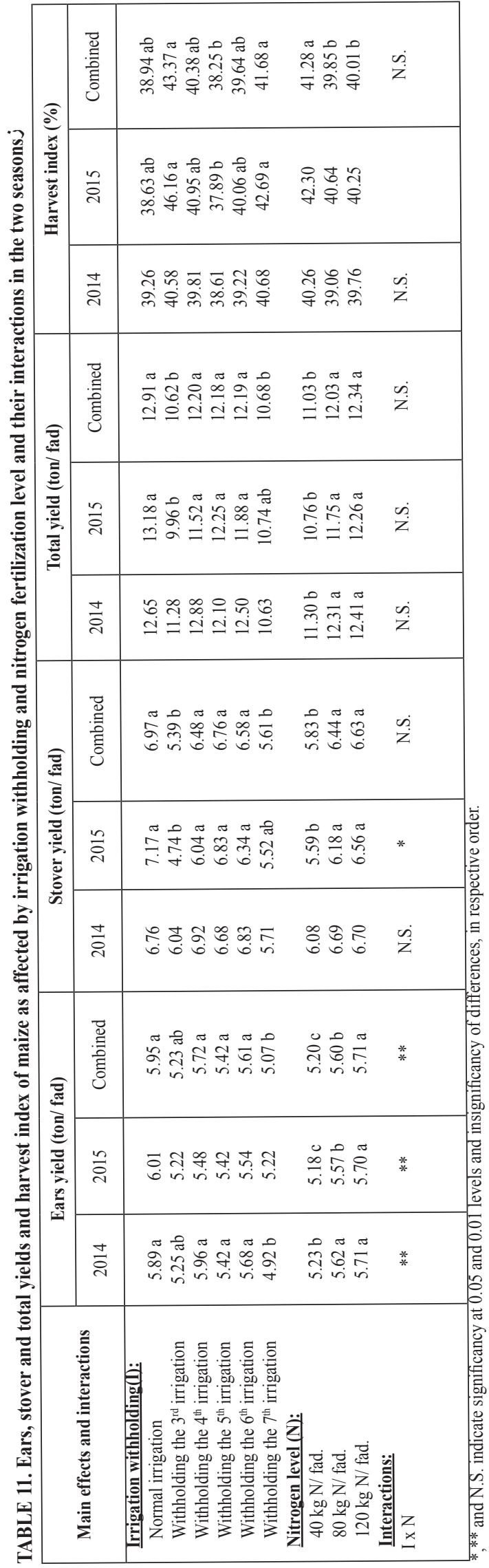

Egypt.J.Agron. Vol.39, No.1 (2017)

\section{Interaction effect}

According to the combined analysis ears yield per fad was significantly affected by $\mathrm{I} x \mathrm{~N}$ interaction (Table 12). This interaction effect was observed in the grain yield/ fad (Table 10) and could account for the present interaction indicating the need for more $\mathrm{N}$ additions when irrigation was withheld and in particular in the $7^{\text {th }}$ irrigation. Several studies stressed on the need for newly reduced $\mathrm{N}$ during grain filling in maize. Shortage of water during post silking needs to be compensated by more $\mathrm{N}$ addition (Below et al., 1981).

TABLE 12. Ears yield (ton/ fad) of maize as affected by irrigation withholding and nitrogen fertilization level interaction (combined data).

\begin{tabular}{|c|c|c|c|}
\hline \multirow{2}{*}{$\begin{array}{l}\text { Irrigation } \\
\text { withholding }\end{array}$} & \multicolumn{3}{|c|}{$\mathbf{N}$ level } \\
\hline & $\begin{array}{l}40 \mathrm{~kg} \\
\mathrm{~N} / \mathrm{fad}\end{array}$ & $\begin{array}{l}80 \mathrm{~kg} \\
\mathrm{~N} / \mathrm{fad}\end{array}$ & $\begin{array}{l}120 \mathrm{~kg} \\
\mathrm{~N} / \mathrm{fad}\end{array}$ \\
\hline \multirow{2}{*}{ Normal irrigation } & A & A & A \\
\hline & $5.75 \mathrm{a}$ & $6.20 \mathrm{a}$ & $5.89 \mathrm{a}$ \\
\hline \multirow{2}{*}{$\begin{array}{l}\text { Withholding the } 3^{\text {rd }} \\
\text { irrigation }\end{array}$} & $\mathrm{B}$ & $\mathrm{B}$ & A \\
\hline & $5.15 \mathrm{a}$ & $4.91 \mathrm{~b}$ & $5.64 \mathrm{a}$ \\
\hline \multirow{2}{*}{$\begin{array}{l}\text { Withholding the } 4^{\text {th }} \\
\text { irrigation }\end{array}$} & $\mathrm{B}$ & A & A \\
\hline & $5.21 \mathrm{a}$ & $6.14 \mathrm{a}$ & $5.81 \mathrm{a}$ \\
\hline \multirow{2}{*}{$\begin{array}{l}\text { Withholding the } 5^{\text {th }} \\
\text { irrigation }\end{array}$} & $\mathrm{B}$ & $\mathrm{AB}$ & A \\
\hline & $5.13 \mathrm{a}$ & $5.35 \mathrm{~b}$ & $5.78 \mathrm{a}$ \\
\hline \multirow{2}{*}{$\begin{array}{l}\text { Withholding the } 6^{\text {th }} \\
\text { irrigation }\end{array}$} & A & A & A \\
\hline & $5.69 \mathrm{a}$ & $5.44 \mathrm{~b}$ & $5.70 \mathrm{a}$ \\
\hline \multirow{2}{*}{$\begin{array}{l}\text { Withholding the } 7^{\text {th }} \\
\text { irrigation }\end{array}$} & $\mathrm{B}$ & $\mathrm{A}$ & $\mathrm{A}$ \\
\hline & $4.29 \mathrm{~b}$ & $5.50 \mathrm{~b}$ & $5.41 \mathrm{a}$ \\
\hline
\end{tabular}

Mean values in the same column for each trait followed by the same lower-case letter are not significantly different according to Duncan's multiple range test at $\mathrm{P} \leq 0.05$.

\section{Grain protein and carbohydrates content}

Irrigation withholding treatments effect

According to combined analysis, grain protein and carbohydrates content generally decreased significantly due to irrigation withholding (Table 13 ). The missing $5^{\text {th }}$ irrigation had the more injury effect on protein content by $5.89 \%$ compared to normal irrigation treatment. It is may be due to the dilution effect. Similar results were reported by Mohsen et al. (2012). Normal irrigation or missing $7^{\text {th }}$ irrigation treatment gave higher grain carbohydrates percentage in comparison to other treatments.

\section{Nitrogen level effect}

Each increase in $\mathrm{N}$ level was reflected in a significant increase in grain protein content up to 
the addition of $120 \mathrm{~kg} \mathrm{~N} /$ fad (Table 13). While, the increase of $\mathrm{N}$ level to $80 \mathrm{~kg} \mathrm{~N} /$ fad produced significant increase in carbohydrates content. These results are in harmony with those reported by Soliman \& Gharib (2011), Xiaobin et al. (2011), El-Naggar et al. (2012) and Darwich (2013).

\section{Interaction effect}

According to the combined analysis, grain protein content was significantly affected by I x $\mathrm{N}$ interaction (Table 14). The interaction between applying $120 \mathrm{~kg} \mathrm{~N} / \mathrm{fad}$ under the missing $6^{\text {th }}$ or $7^{\text {th }}$ irrigations led to a significant increase in grain protein content, followed by $80 \mathrm{~kg} \mathrm{~N} /$ fad under the missing $4^{\text {th }}$ irrigation treatment.

\section{ACKNOWLEDGEMENT}

The authors are grateful to Prof. Dr. Ahmed A. Abdul Galil, Professor of Agronomy, Faculty of Agriculture, Zagazig University for valuable suggestions and revising this paper.

TTABLE 13. Grain protein and carbohydrates content of maize as affected by irrigation withholding and nitrogen fertilization level and their interactions in the two seasons.

\begin{tabular}{|c|c|c|c|c|c|c|}
\hline \multirow[b]{2}{*}{ Main effects and interactions } & \multicolumn{3}{|c|}{ Grain protein content $(\%)$} & \multicolumn{3}{|c|}{ Grain carbohydrates content (\%) } \\
\hline & 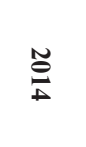 & 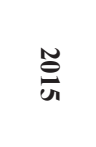 & 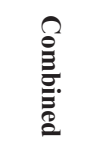 & 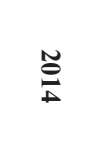 & 气̆ & 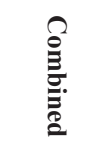 \\
\hline \multicolumn{7}{|l|}{ Irrigation withholding(I): } \\
\hline Normal irrigation & $8.31 \mathrm{~b}$ & $8.65 \mathrm{a}$ & $8.48 \mathrm{a}$ & $73.39 \mathrm{a}$ & $72.64 \mathrm{a}$ & $73.01 \mathrm{a}$ \\
\hline Withholding the $3^{\text {rd }}$ irrigation & $8.32 \mathrm{~b}$ & $8.22 \mathrm{ab}$ & $8.27 \mathrm{ab}$ & $68.83 \mathrm{~b}$ & $70.09 \mathrm{ab}$ & $69.46 \mathrm{~b}$ \\
\hline Withholding the $4^{\text {th }}$ irrigation & $8.82 \mathrm{a}$ & $8.66 \mathrm{a}$ & $8.74 \mathrm{a}$ & $68.56 \mathrm{~b}$ & $70.68 \mathrm{ab}$ & $69.62 \mathrm{~b}$ \\
\hline Withholding the $5^{\text {th }}$ irrigation & $7.89 \mathrm{~b}$ & $8.07 \mathrm{~b}$ & $7.98 \mathrm{~b}$ & $69.61 \mathrm{~b}$ & $68.59 \mathrm{ab}$ & $69.10 \mathrm{~b}$ \\
\hline Withholding the $6^{\text {th }}$ irrigation & $8.83 \mathrm{a}$ & $8.43 \mathrm{ab}$ & $8.63 \mathrm{a}$ & $69.37 \mathrm{~b}$ & $68.29 \mathrm{~b}$ & $68.83 \mathrm{~b}$ \\
\hline $\begin{array}{l}\text { Withholding the } 7^{\text {th }} \text { irrigation } \\
\text { Nitrogen level }(\mathbf{N}) \text { : }\end{array}$ & $8.82 \mathrm{a}$ & $8.98 \mathrm{a}$ & $8.90 \mathrm{a}$ & $72.65 \mathrm{a}$ & $73.10 \mathrm{a}$ & $72.87 \mathrm{a}$ \\
\hline $40 \mathrm{~kg} \mathrm{~N} / \mathrm{fad}$ & $8.26 \mathrm{c}$ & $8.11 \mathrm{c}$ & $8.18 \mathrm{c}$ & 69.64 & 69.87 & $69.75 \mathrm{~b}$ \\
\hline $80 \mathrm{~kg} \mathrm{~N} / \mathrm{fad}$ & $8.47 \mathrm{~b}$ & $8.41 \mathrm{~b}$ & $8.44 \mathrm{~b}$ & 70.55 & 70.60 & $70.57 \mathrm{ab}$ \\
\hline $120 \mathrm{~kg} \mathrm{~N} / \mathrm{fad}$ & $8.77 \mathrm{a}$ & $8.99 \mathrm{a}$ & $8.88 \mathrm{a}$ & 71.02 & 71.23 & $71.12 \mathrm{a}$ \\
\hline Interactions: & & & & & & \\
\hline $\mathrm{I} \times \mathrm{N}$ & $* *$ & $* *$ & $* *$ & N.S. & N.S. & N.S. \\
\hline
\end{tabular}

TABLE 14. Grain protein content (\%) of maize as affected by irrigation withholding and nitrogen fertilization level interaction (combined data).

\begin{tabular}{|c|c|c|c|}
\hline \multirow[b]{2}{*}{ Irrigation withholding } & \multicolumn{3}{|c|}{ N level } \\
\hline & $\begin{array}{l}40 \mathrm{~kg} \\
\mathrm{~N} / \mathrm{fad}\end{array}$ & $\begin{array}{l}80 \mathrm{~kg} \\
\mathrm{~N} / \mathrm{fad}\end{array}$ & $\begin{array}{l}120 \mathrm{~kg} \\
\mathrm{~N} / \mathrm{fad}\end{array}$ \\
\hline \multirow[b]{2}{*}{ Normal irrigation } & $\mathrm{A}$ & B & $\mathrm{A}$ \\
\hline & $8.67 \mathrm{a}$ & $8.06 \mathrm{~b}$ & $8.70 \mathrm{a}$ \\
\hline \multirow[b]{2}{*}{ Withholding the $3^{\text {rd }}$ irrigation } & $\mathrm{B}$ & $\mathrm{A}$ & $\mathrm{A}$ \\
\hline & $7.19 \mathrm{~b}$ & $8.41 \mathrm{~b}$ & $8.50 \mathrm{ab}$ \\
\hline \multirow{2}{*}{ Withholding the $4^{\text {th }}$ irrigation } & $\mathrm{B}$ & $\bar{A}$ & $\bar{A}$ \\
\hline & $7.88 \mathrm{a}$ & $9.20 \mathrm{a}$ & $9.14 \mathrm{a}$ \\
\hline \multirow{2}{*}{ Withholding the $5^{\text {th }}$ irrigation } & $\mathrm{B}$ & $\mathrm{A}$ & $\mathrm{A}$ \\
\hline & $7.50 \mathrm{ab}$ & $8.38 \mathrm{~b}$ & $8.06 \mathrm{~b}$ \\
\hline \multirow{2}{*}{ Withholding the $6^{\text {th }}$ irrigation } & $\mathrm{B}$ & $\mathrm{B}$ & $\mathrm{A}$ \\
\hline & $8.20 \mathrm{a}$ & $8.26 \mathrm{~b}$ & $9.44 \mathrm{a}$ \\
\hline \multirow{2}{*}{ Withholding the $7^{\text {th }}$ irrigation } & $\mathrm{B}$ & $\mathrm{C}$ & $\mathrm{A}$ \\
\hline & $8.94 \mathrm{a}$ & $8.32 \mathrm{~b}$ & $9.44 \mathrm{a}$ \\
\hline
\end{tabular}

Mean values in the same column for each trait followed by the same lower-case letter are not significantly different according to Duncan's multiple range test at $\mathrm{P} \leq 0.05$. 


\section{REFERENCES}

Abd Alla, A.A. (2005) Maize yield potentiality in response to bio and mineral nitrogen fertilizers under drip irrigation regimes in the hewly reclaimed soils. $J$. Agric. Sci. Mansoura Univ. 30 (10), 5765-5779.

Abd El-Rheem, Kh. M., Zaghloul, Sahar M. and Mahdy, Hayam A. A. (2015) Effect of phosphorus and potassium fertilization on growth and yield of corn plants under different natural soil amendments. Sci. Agric. 9 (2),70-75.

Abdul Galil, A.A., Basha, H.A., Mowafy, S.A.E. and Mohamed, Seham M. (2003) Effect of phosphorus addition on the response of four wheat cultivars to $\mathrm{N}$ fertilization level under sandy soil conditions. Minufiya J. Agric. Res. 28(1),1-22.

Achieng, J.O., Ouma, G., Odhiambo, G. and Muyekho, F. (2010) Effect of farmyard manure and inorganic fertilizers on maize production on Alfisols and Ultisols in Kakamega, western Kenya. Agric. Biol. J. N. Am. 1 (4), 430-439.

Ash-Shormillesy, S.M.A.I. (2005) Effect of splitting different nitrogen fertilizer levels on productivity of maize. Zagazig J. Agric. Res. 32 (1),1-21.

Atia, A.A. and Mahmoud, A.A. (2006) Economic study to evaluate the nitrogen response curve in maize. J. Agric. Sci. Mansoura Univ. 31(4), 1837-1846.

Bader, M.M., Bassal, S.A.A. and Ibrahim, E.M. (2003) Effect of preceding winter crops, nitrogen and phosphorous fertilizer levels on growth and yield of maize (Zea mays L.). J. Agric. Sci. Mansoura Univ. 28 (9), 6591-6601.

Below, F.E., Christensen, L.E., Reed, A.J. and Hageman, R.H. (1981) Availability of reduced N and carbohydrates for ear development of maize. Plant Physiol. 68, 1186-1190.

Darwich, M.M.B. (2013) Effect of N rates, compost and humic acid treatments on growth and yield components of maize. Ph. D. Thesis in Agron., Fac. Agric. Mansoura Univ., Egypt.

Darwish, A.A. (2003) The yield and yield components of maize as influenced by nitrogen, zinc and boron fertilization. J. Agric. Sci. Mansoura Univ. 28 (2), 799810 .

Egypt.J.Agron. Vol.39, No.1 (2017)
El-Azab, A.A.S. (2012) Response of maize to organic and mineral fertilization under foliar application treatments. Ph. D. Thesis in Agron., Fac. Agric. Mansoura Univ., Egypt.

El-Metwally, I.M., Ahmed, S.A. and Sad El-Din, S.A. (2001) Nitrogen fertilizer levels and some weed control treatments effect on maize and its associated weeds. J. Agric. Sci., Mansoura Univ. 26 (2), 585-601.

El-Murshedy, W.A. (2002) Response of some maize cultivars to nitrogen fertilization under two farming system. J. Agric. Sci. Mansoura Univ. 27(5), 28212835.

El-Naggar, N.Z.A., Mohamed, M.A., Mowafy, S.A. and Abd El-Hameed, I.M. (2012) Effect of FYM and $\mathrm{N}$ fertilizer on photosynthetic partitioning parameters, yield and yield attributes of maize-soybean intercropping. Zagazig J. Agric. Res. 39 (4), 589-604.

El-Shahed, H.M., Saleh, M.E. Mowafy, S.A. and Osman, M.M.A. (2013) Effect of planting density and skipping irrigation at certain growth stages on yield potentiality of some maize hybrids. Zagazig J. Agric. Res. 40 (4), 617-646.

El-Sobky, E. E. M., Zeidan, E. M., Abdul Galil, A. A. and Geweifel, H. G. (2014) Effect of irrigation interval, organic manuring and nitrogen fertilization level on yield and yield attributes of maize. Zag. J. Agric. Res. 41 (1), 1-20.

Elzubeir, A. O. and Mohamed, A. E. (2011) Irrigation scheduling for maize (Zea mays L.) under desert area conditions- North of Sudan. Agric. Biol. J. N. Am. 2 (4),645-651.

Farre, I. and Faci, J.M. (2009) Deficit irrigation in maize for reducing agricultural water use in a Mediterranean environment. Agricultural Water Management, 96, 383-394.

Gomez, K.N. and A.A. Gomez (1984) "Statistical Procedures for Agricultural Res.", John Wiley and Sons, New York, $2^{\text {nd }}$ ed. p. 68.

Hameedi, I. H., Ati, A. S. and Jasim, H. M. K. H. (2015) Effect of irrigation period and organic fertilization (TOP10) on growth, production and water use by maize crop. J. Agric. Veter. Sci. 8 (5),1-4.

Hussein, S.M.A. and El-Melegy, A.M. (2006) Maize yield and its attributes as affected by cropping 
sequences, water requirements and sources of nitrogen fertilization under drip irrigation system in sandy soil. Zagazig J. Agric. Res. 33 (6), 1043-1062.

Ibrahim, S.A. and Kandil, H. (2007) Growth, yield and chemical constituents of corn (Zea mays L.) as affected by nitrogen and phosphorus fertilization under different irrigation intervals. J. Appl. Sci. Res. 3 (10), $1112-1120$.

Iqbal, M.A., Bodner, G., Heng, L.K., Eitzinger, J. and Hassan, A. (2010) Assessing yield optimization and water reduction potential for summer-sown and spring-sown maize in Pakistan. Agricultural Water Management, 97, 731-737.

Jakson, M.L. (1967) "Soil Chemical Analysis" Constable Co. LTd. London.

Mahama, G.Y, , Mahama, P. V., Vara Prasad, Kraig L., Roozeboom, Jesse B. Nippert and Charles W. Rice (2016) Response of maize to cover crops, fertilizer nitrogen rates and economic return. Agron. J. 108,17-31.

Mohamed, A.M.A. (2006) Effect of some biochemical fertilization regimes on yield of maize. M.Sc. Thesis, Fac. Agric., Zagazig Univ., Egypt.

Mohsen T., R. Zarghami, M.M.A. Boojar and M. Oveysi (2012) Effects of drought stress and different nitrogen levels on morphological traits of proline in leaf and protein of corn seed (Zea mays L.) AmericanEurasian J. Agric. \& Environ. Sci. 12 (1), 49-56.

Neter, J., Wasserman, W. and Kutner, M.H. (1990) "Applied Liner Statistical Model". $3^{\text {rd }}$ ed. IRWIN, Boston, MA. USA.

Snedecor, G.W. and Cochran, W.G. (1967) "Statistical Methods". 5th ed. Iowa State Univ. Press, Iowa, USA.

Sokht-Abandani, R. R. and Ramezani, M. (2012) The examination of the effect of irrigation interval and nitrogen amount on the yield and yield components of maize (Zea mays L. CV. Single cross 704) in Mazandaran Provience. Interl. J. Bio. 4 (2), 70-78.

Soliman, I.E. and Gharib, H.S.(2011) Response of weeds and maize (Zea mays L.) to some weed control treatments under different nitrogen fertilizer rates. Zagazig J. Agric. Res. 38 (2), 249-271.

Xiaobin, W., Dai, K., Zhang, D., Zhang, X., Wang, Y., Zhao, Q., Cai, D., Hoogmoed,W. B. and Oenema, O. (2011) Dry land maize yield and water use efficiency in response to tillage/crop stubble and nutrient management practices in China. Field Crop Res. 120 (1), 47-57. 


\section{تأثثير إسقاط الري ومستوي التسميد التيتروجيني علي محصول الذرة}

السيد السيد أحمد السبكي و نهال زهدي عبد الباسط النجار

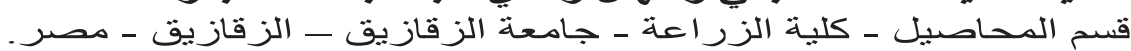

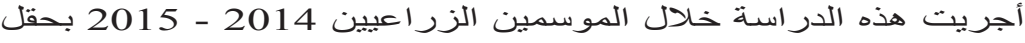

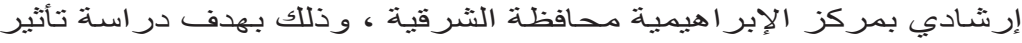

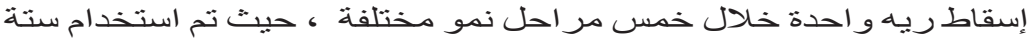

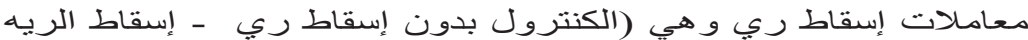

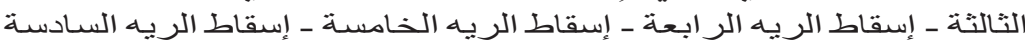

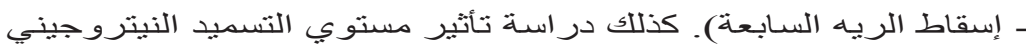

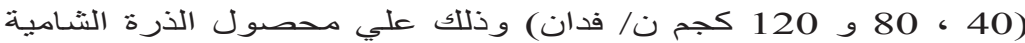
ومساهماته. ويمكن تخليص النتائج المتحصل ولن عليها علي النحو التالي:

كان لإسقاط الري تأثيراً معنوياً علي محصول الذرة الثـامية

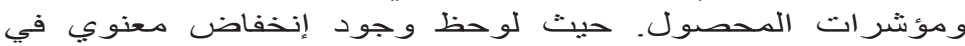
كل من طول وقطر الكوز، عدد حبوب السطر، وزبو وزن 100 حبة،

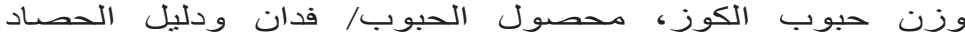
نتيجة إسقاط الرية الثالثة، الرية الخامسة أو الرية الرية الريابعة. أدي زيسادة مستوي النيتروجين حتي 120 كجم ن/ نالرة فـدان إلي التي

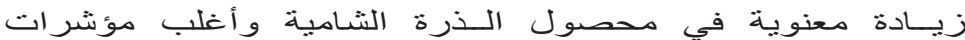

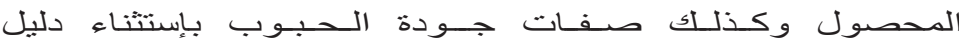
الحصاد والـذي إنخفض بزيادة مستوي التسميد النيتروجيني.

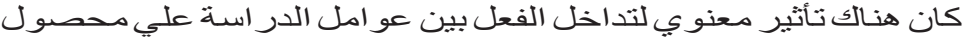

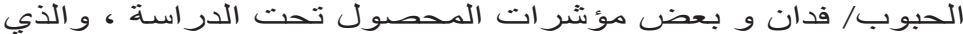

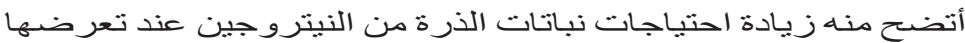

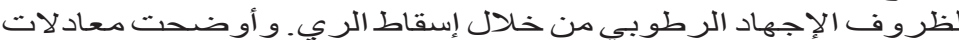

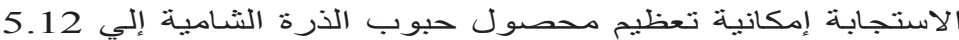
طن/ فدان بإضـافة 86.67 كجم ن/ فدان فقط عند الري كل 12 يوم.
} 